\title{
The Knowledge-based Agricultural Cooperative: A Validation from the Trentino Case ${ }^{*}$
}

\section{ABSTRACT}

The new agri-food market is considered a detrimental factor for the competitiveness and financial equilibria of agricultural cooperatives. According to this view, as a result of market saturation and globalisation processes, shifting investments to supply chain forward activities (e.g., for brand development or for research and development activities) would represent a serious threat to the cooperative model. Taking a contrasting view, this paper aims at demonstrating that the cooperative model continues to play a strategic role in the current competitive environment. In particular, the adoption of the knowledge-based theory of the firm combined with the "open innovation" approach permits a renewed interpretation of the role of modern agricultural cooperatives as knowledge developers and disseminators, for the benefit of members and their communities. This theoretical approach will be tested by studying a sample of agricultural cooperatives operating in the province of Trento, in North-East Italy.

\section{KEY-WORDS}

AGRICULTURAL COOPERATIVES, AGRI-FOOD SECTOR, INNOVATION, KNOWLEDGE CREATION AND TRANSFER

\section{Acknowledgments}

The authors would like to thank the anonymous reviewers for comments and suggestions. We are also grateful to colleagues at Euricse and to the Federation of the Trentino Cooperatives and the agricultural cooperatives involved in the survey conducted during the research for this study.

The entire research project was designed, developed and carried out by Eddi Fontanari, who is also the first author of this article.

JEL Classification: Q13, O31, O35, L23 | DOI: http://dx.doi.org/10.5947/jeod.2019.008 


\section{Introduction}

This work is an attempt to stress the importance of the immaterial factors justifying the existence of modern agricultural cooperatives (cf. Fontanari, 2014; 2017). Research has paid great attention to price determination of agricultural produce, which assumed especial relevance because of its perishable nature (Ward, 1982), as well as to the weaknesses of the property and governance structure of the cooperative organisational arrangement (Cook, 1995; Nilsson, 2001; Chaddad and Cook, 2004; Cook and Burress, 2009). Above all, in the current agri-food market scenario, this structure is considered a detrimental factor in the competitiveness and financial equilibria of agricultural cooperatives in a context in which market changes have particularly affected consumer preferences, whose demands have shifted towards more differentiated and high-quality products, which require customer-led production. The first critical point raised by the literature concerns the capacity of a firm controlled by farmers, which is producer-oriented and set up to safeguard their interests, to respond to market pressures with a more market-oriented corporate strategy. In addition, the saturation of the agri-food market (Folmer et al., 1995) has led to an ever-greater product differentiation to enable producers to face competitors and gain market niches. This context requires high-innovation production. The farmers are thus involved in a process of agricultural industrialisation that requires the use of greater financial resources and, consequently, a sectorial shift towards capital-intensive production (Cook, 1995).

Based on this scenario, the shift of dedicated investments towards the supply chain forward processes (e.g., for brand development or for research and development activities) would represent a serious threat to the cooperative model (Hendrikse and Veerman, 2001). In fact, its "ill-defined" property rights (Cook, 1995; Cook and Iliopoulos, 2000) may result in inadequate financial resources downstream, where producers operate (Hendrikse and Veerman, 2001).

However, these considerations do not take into sufficient account the potential strengths in terms of knowledge integration (and coordination) embedded in the agricultural cooperative model. Though some of the literature has recognised the increasing importance and strategic role of knowledge and of its management in the agri-food chain (Sporleder and Moss, 2002; Sporleder and Peterson, 2003; Sporleder, Jackson and Bolling, 2005; Sporleder, 2006; Sporleder and Wu, 2006; Sporleder and Boland, 2011), knowledge seems to assume the nature of a ware to be delivered from one agent to another. In particular, these contributions stress its transfer from the growers (agricultural production) to the downstream/consumer level (IP traceability, cf. Sporleder and Goldsmith, 2001; Goldsmith and Bender, 2004). Attention has been paid mainly to qualitysignalling strategies (Sporleder and Goldsmith, 2001) and therefore to the produce's attributes (extrinsic and/or credence). In this way, the nature and role of knowledge have been restricted to this heuristic meaning. As a result, according to this perspective, the more important task of firms operating in the different nodes of the agri-food chain is to favour a communication channel between the upstream and downstream actors in order to achieve coordination among them. Knowledge is, therefore, defined mainly with reference to the product's attributes and to the product's movements and logistic from one node to another, where effective coordination determines a crucial advantage 
in the context of perishable goods. Clearly, the proposed interpretation represents a rather myopic vision of both the nature and role of knowledge in the agri-food sector.

A step forward has been taken with the introduction of the concept of "open innovation" (Chesbrough, 2003). This approach emphasises that competitiveness is not based only on internal research and development activity but rather on the ability of establishing links with other external strategic actors in the knowledge chain (Sacchetti, 2009). Because of its aims and self-management features, the cooperative form in particular offers a favourable governance context for developing value chains in which knowledge is shared on a reciprocal basis for the mutual benefit of members and communities. The agricultural cooperative is an institutional setting in which producers as members of the cooperative run a much lower risk of falling into subordinate positions or bearing the costs of market failures (see, for example, Parrilli and Sacchetti, 2008 for an application within networks and clusters). More recently, this concept has also been used for the interpretation of the agri-food sector, especially with reference to the innovation process (Tushman, Lakhani and Lifshitz-Assuf, 2012; Bigliardi and Galati, 2013; Mäkimattila, Melkas and Uotila, 2013; Medeiros et al., 2016). In fact, in the past, analyses of innovation processes have systematically undervalued the contribution of agriculture. This sector was considered relatively static, with a low knowledgecontent. Today, consumers are more aware than in the past of the importance of food quality and seem to play a more important role in influencing the pace of innovation in processes and production. This new push coming from the ultimate value chain ring (the informed consumer) is known as "chain reversal" (Bigliardi and Galati, 2013). In this new scenario, the capability to innovate has assumed a fundamental and strategic role in the agri-food sector. In particular, if a farm intends to be competitive, it has to be able to satisfy consumer preferences.

Although the literature has begun to frame this sector, in none of these contributions is there a reference to the strategic role of the agricultural cooperative in sharing knowledge, improving members' capabilities and ultimately stimulating the innovation process and consumers' welfare. The lack of attention to this enterprise form and sector is telling and confirms once again the difficulty of understanding, both at the scientific level and in terms of strategy and policy, the variety of activities and functions performed by modern agricultural cooperatives ${ }^{1}$.

The role of agricultural cooperatives has been previously analysed by Giannakas and Fulton (2005), who studied input-supplying cooperatives and their impact on industry innovation, prices

\footnotetext{
Recently, an effort to update the coordination challenge in the agri-food chain has been made by Bijman, Muradian, Cechin (2011) and Cechin (2013) using a transaction cost approach. Feng and Hendrikse's contribution (Feng and Hendrikse, 2011) also represents an effort to deepen the role of the agricultural co-op against the investor-owned firm (IOF) in coordinating the actions of different agents of the agri-food chain but without placing emphasis on the social process at the basis of knowledge production, sharing and diffusion. Instead, in the past, Sexton and Iskow (1988) discussed, only briefly and in a general way, the potentialities of marketing cooperatives in coordinating production and marketing but only with regard to improving quality assurance as a strategy to obtain a better price for the finished product. In addition, a first interesting recognition of the economic justification and functions of agricultural cooperatives was made by Shaffer (1987).
} 
and social welfare in the context of a mixed oligopoly structure. Results support the view that producers' involvement in cooperative innovation leads to a greater innovation for this enterprise type compared to investor-owned enterprises "because it internalizes the effect of reduced costs and prices (due to process innovation) on the welfare of its members. This internalization occurs because the co-op maximizes member welfare rather than profits" (ibid.: 418).

In light of the above, this paper attempts to update the economic functions of the modern agricultural cooperative and the specificity of its governance, using a knowledge-based approach. While knowledge and capabilities are usually analysed in pursuit of a competitive advantage not to be shared with others, here (because of the aims and governance of cooperatives) we observe knowledge sharing among co-operators in pursuit of common advantages. The novelty of this research is that we apply knowledge concepts in a context defined by democratic governance, through which producers cooperate to share knowledge in view of furthering their common welfare. This in turn means that knowledge is used to upgrade the status of all actors within the cooperation project and to extend that knowledge to the value chain overall. In this respect, there is a close link between this enterprise form on the one hand, and the extension of the benefits of the innovation process in agriculture and the entire agri-food chain on the other. In fact, the property and governance structure seems to favour the development of communities of practice with a central role for farmers in the pursuit of a collective goal. This condition has important implications for the sense of belonging and involvement of members. It fosters both the sustainability of the cooperative and the efficiency of the whole chain beyond the mere competitiveness of a farm.

Starting from these assumptions, the work is structured as follows. After introducing an overview of the main conceptual framework, the paper presents data on the province of Trento (Italy). Data analysis offers explorative insights on the knowledge-related functions of the modern agricultural cooperative.

\section{Knowledge and absorptive capacity: theoretical background}

To adequately understand and inform the functions of modern agricultural cooperatives, it is necessary to mingle elements of the knowledge-based theory of the firm with the cooperative nature of governance in agricultural cooperatives and the innovation approach these organisations take. By so doing, we can define a realistic and comprehensive approach to study the role of knowledge in agricultural production, linking it to a new interpretation of the innovation process. In parallel, this focus allows us to highlight some of the strengths of the agricultural cooperative's institutional and organisational architecture.

Knowledge and its role within firms has been debated in economics as well as management to the extent that firms have been explained not only in terms of their ability to minimise transaction costs or reduce agency problems but also in terms of their ability to promote knowledge creation, use and transferability, as well as innovation (Foss, 1993; Kogut and Zander, 1993; Nonaka and Takeuchi, 
1995; Loasby, 2006). Complementary evolutionary approaches, building on the seminal work of Nelson and Winter (1982), have explained how organisations develop capabilities or routines. With some exceptions (Spender, 1996; Grandori, 2001), less has been written on how these functionalities relate to cooperative governance and, more specifically, how cooperation models in agriculture can influence knowledge creation, use and transfer to the benefits of members.

Before progressing with our analysis, let us clarify what information and knowledge are in the first place. Information can be described as the raw data potentially available in a certain context (e.g., in the form of available technology). The capacity of detecting, selecting and adapting relevant information, as Simon (1991) notably emphasised, is bounded and leads to satisfactory rather than to optimal decisions. Knowledge derives from a process of knowing and, in modern times, was early analysed by Michael Polanyi (1966) ${ }^{2}$. Polanyi's work emphasised that, besides reasoning, the major sources of learning or acquisition of knowledge are related to practice and experience. Experiential (or tacit) knowledge, which can be mainly transmitted by sharing day-to-day activities and generally cannot be codified in blueprints or codes of practice, takes central stage in this view, and Nonaka and Takeuchi (1995) analysed experiential knowledge in the context of firms. They developed a knowledge spiral model in which tacit and codified knowledge interact in an interpretative process enabled by organisational solutions that favour relationality and socialisation. In this approach, knowledge transfer among individuals — as per the notion of tacit knowledge-is very much an intersubjective, social process. Notably, the knowledge residing in the heads and hands of individuals is not equivalent to organisational knowledge or learning. Individual knowledge moves with individuals from one organisation to another (Simon, 1991), while organisational knowledge and learning are capabilities, bundles of routines that have been learned and stored in the organisation's practices and can be recovered when needed regardless of the presence of specific individuals.

Moreover, the effective application of knowledge within an organisation would need specific "absorptive capacity". This capacity consists of organisational capabilities or routines on the recipient's side that enable the use of existing knowledge. According to Cohen and Levinthal (1989: 569-570), absorptive capacity is "the ability to identify, assimilate, and exploit knowledge from the environment". In other words, the use of knowledge implies that organisations hold the necessary organisational capabilities to make effective use of it. The existence of specific organisational capabilities has explained the different levels of flexibility, innovation and performance of firms within the same sector (Zahra and George, 2002), in contrast to approaches that focussed on the overall competitiveness of the industrial sector (as in Porter, 1990; 2001).

More recently, Lewin, Massini and Peeters (2011) extended the growing body of work developed on these themes. They specified in more detail the ideas of external and internal capabilities introduced by Cohen and Levinthal (1989) and identified their sources. As Mariano and Al-Arrayed (2018) effectively summarised, internal absorptive capacity implies the existence of

\footnotetext{
The origins of these reflections can be however traced back to Greek philosophy.
} 
routines that include the capacity for variation, selection and knowledge sharing of best practices, as well as reflection and the updating and replication of routines. Routines that enable external absorptive capacity complementarity are related to the recognition of useful external knowledge and the capacity to learn from other interacting actors (e.g., partners, suppliers, clients, consultants, competitors). Notably, this work considers socio-cultural values, norms and mechanisms as important moderators. This is a relevant result consistent with the study of the role of cooperatives in agriculture since it highlights the potential of cooperative values and institutional settings for the emergence of absorptive capacity and, therefore, improved innovation-related capabilities.

Absorptive capacity, and knowledge-based theory more broadly, look at the firm as an institution aiming at integrating and coordinating a set of (different) competencies using unique organisational capabilities or routines (Grant, 1996, among others). In this case, the logic underpinning the firm is explainable by the Smithian virtuous circuit of the division of labour-specialisation-increase of productivity/efficiency. Organisational capabilities are distinctive in what an organisation can do that others cannot. Therefore, they are valued to the extent that they may confer a competitive advantage to the organisation within the sector.

The explanation of a firm's existence, from this perspective, is related to integrating specialised knowledge in unique ways. This result can be obtained by defining and organising (higher-order) principle bundles. In fact, "the central advantage of firms in the production process is not simply the avoidance of the transaction costs associated with market exchange, but their 'unique advantages for governing certain types of economic activities from a logic that is very different from that of market"” and "integrating the knowledge of many different individuals in the process of producing goods and services is such a logic" (Grant, 1996: 113). Given that "efficiency in knowledge production (by which I mean the creation of new knowledge, the acquisition of existing knowledge, and storage of knowledge) requires that individuals specialize in particular areas of knowledge" (ibid.: 112). From this viewpoint, the organisational design of interdependencies represents a peculiarity of the firm reflecting managerial choice. In fact, "the division of tasks between individuals and departments and the specification of interfaces between them lies within the domain of organizational design" (Grant, 1996: 114; Willem and Buelens, 2009).

Designing the set of organising principles, such as rules, procedures, norms and conventions, is a pre-condition for coordinating and integrating different knowledge domains. To do so, shared values, language and codes are needed. In this sense, the firm represents a community and sensemaker organisation (Kogut and Zander, 1992; 1996) with the function of building up the formal and informal institutional context within which the interactions that shape the production process can occur and the organising principles operate.

Identifying routines that enable the sharing of knowledge is central to production coordination (Dyer and Nobeoka, 2000; Kogut, 2000). While in an investor-owned firm (and in the value chain it may direct and control) knowledge is typically concentrated and transferred according to the aims and advantages of the stakeholder who is in control of the organisation and its production 
network (typically a restricted group of investors or the management), within a cooperative setting, production coordination can be interpreted as the context in which co-operators achieve mutually beneficial outcomes (Parrilli and Sacchetti, 2008). This result is expected because of the specific type of governance of cooperation, typically characterised by inclusive decision-making, surplus re-investment in indivisible reserves, and common management of assets. The effectiveness of the cooperative project is, therefore, very much tied to the sharing of knowledge about strategic decisions in production, since participation cannot occur without knowledge. This requires a common effort towards the improvement of the skills and knowledge of each and every co-operator (Sacchetti and Sugden, 2003).

In particular, consolidated routines create the conditions to favour and foster the speed of knowledge transfer and sharing among co-operators. This is relevant for both codified and tacit knowledge, and for the latter in particular, given its relational nature. By creating coherent sets of routines, the cooperative can promote learning even by means of a "storytelling" mechanism ${ }^{3}$ (Brown and Duguid, 1991) among individuals with different roles within the firm, which is extremely conducive to (tacit) experiential knowledge, eventually stimulating a social innovation process by means of variety and selection. From this viewpoint, the firm can be defined as the community of communities of practice (ibid.). These communities enable a social and operational context conducive to sharing and solving common problems thanks to the presence of a strong identity that binds the participants (practitioners) in the pursuit of a collective goal.

A consistent approach, but with a focus on external absorptive capacity, has been used by Chesbrough (2003), who introduced the concept of "open innovation". The author underlined the importance for the single firm of identifying and exploiting knowledge-related interdependencies with other actors by looking beyond organisational boundaries. This strategy works towards internalising and co-producing new knowledge and innovation. The idea that knowledge is dispersed and that production and economies more broadly require coordination mechanisms in conditions of complexity and uncertainty was emphasised by Hayek (1945) long ago, as well as by Richardson (1972), who explained networking among firms in terms of competence similarities and diversity. Several authors, following these seminal contributions, have emphasised that part of the competencies and strategic knowledge needed by a firm lies outside its boundaries and that the most efficient and least expensive way to use these competencies and knowledge is to set up collaborative networks with external strategic actors (Sacchetti, 2009; Ye and Kankanhalli, 2013).

\section{Building bridges between knowledge and "agriculture practice"}

If we consider the agri-food chain and the great transformations it underwent over the last few decades, it is possible to understand the explicatory power of an approach that combines

\footnotetext{
Stimulating and assuring a certain level of "cognitive heterogeneity" (cf. Nooteboom et al., 2007).
} 
knowledge with the inclusive governance features of cooperation. The sector has faced a reversal of the traditional paradigm: more and more consumers influence the (qualitative) attributes of farming production (Bigliardi and Galati, 2013). Unlike in the past, the attention paid by the market to credence attributes, such as environmental protection, work security, distributive equity, healthfulness, etc., has led to a significant increase in the importance of continuously introducing innovations that support this wide array of societal concerns.

The level of complexity required by the agri-food sector would be unachievable by individual farms, especially if they are family-sized and farming does not constitute the main economic activity of the family (Fontanari, 2018). Market demand and competition require that producers apply more sophisticated knowledge, which can be obtained if producers enter the value chain not as substitutable suppliers (according to arm's-length relations) but as learners, who can contribute to improving the quality of final products. This is possible if the production process articulated within the value chain supports learning and the development of external absorptive capacity by providing farmers with training and support services. In this regard, it is increasingly necessary to define an institutional architecture favouring efficient chain coordination with the active involvement of growers.

This need has also been emphasised by European policies with the adoption of the Rural Development Programme. This programme sets as one of its main priorities the transfer of externally produced knowledge and technologies to farms. In this regard, European policy-makers suggest the building up of operational groups (environments) involving all the strategic stakeholders (e.g., farmers, processors, retailers, universities, research institutes, etc.) of the agri-food chain in order to promote a knowledge socialisation process and the identification of real priorities/problems to be solved collectively.

This framework is also consistent with Engel (1995), who discussed the social organisation of innovation in agriculture. Engel's contribution is informative for understanding the real process of knowledge and innovation exchange in agriculture. According to this approach, innovation in agriculture progresses by means of an interplay between practices in order to (re-) define and pursue a shared agricultural development pattern (World Bank, 2008). As a result of this exchange (between social practices), the agricultural model and the practices are upgraded. The definition of a good farmer or a good technical specialist is meant to be an outcome of this process. In fact, the competent performance of a specific practice is not only regulated by the defining and experience rules developed within that practice but is also influenced by non-practitioners (lay individuals). So, for example, the agricultural extension service benefits from the insights of farmers (practice) and vice versa, and so on. For this reason, the agri-food chain can be renamed "agriculture practice". This concept represents the essence of the "social theatre" characterising the innovation in agriculture according to Engel's vision. In fact, he introduced this term to underline the exchange of ideas, world views and knowledge understood as information and know-how at the basis of a continuous (re-) definition of practices and the agricultural development pattern 
(Garcia-Winder et al., 2009). This last step represents the intersection between his approach and the knowledge-based theory of the firm. The dynamics underlined in the "social theatre" of innovation in agriculture are very similar to those depicted in the firm as a social community and in the concept of "open innovation" (Berkhout, Hartmann and Trott, 2010).

Finally, it is interesting to note that this type of innovation process (networking à la Engel) in agriculture lies at the opposite side of the linear model based on a top-down approach (Sulaiman and Hall, 2002; World Bank, 2006; 2008; Agwu, Dimelu and Madukwe, 2008; Knickel et al., 2009; Minh, Neef and Hoffmann, 2011; Akkoyunlu, 2013). In fact, in Engel's model, there is a co-participation in agriculture innovation and no practice has a more important role than the others do. Each practice is equally significant, and the farmers play a strategic role.

Starting from these considerations, the next section introduces a concept of agricultural cooperative meant as a specific organisational form that combines inclusivity in governance with an operational structure aimed at fostering innovation among co-operators.

\section{Agricultural cooperatives: an institutional design for fostering innovation in agriculture}

Within a cooperation project, farmers' production activities require several strands of specialised knowledge and the cooperative represents the institution that integrates and coordinates this different, specialised knowledge. In this case, each of these specialised groups constitutes a practice and so, besides the co-op divisions, even the farmers are a specific practice. The borders of the agricultural cooperative include complementary sets of knowledge that are relevant for a specific agricultural practice. From this viewpoint, the agricultural cooperative represents a community of communities (of practices), a sense-making organisation that by means of an organising set of principles facilitates the interplay among a variety of communities. In the case of agricultural cooperatives, the cooperative values and principles ${ }^{4}$ establish an anchor for building the community identity. The construction of an identity has been considered a pre-condition for the construction of a (an innovative) production system (World Bank, 2008; Anandajayasekeram, 2011). Where innovation processes are supported by a common identity, a shared learning process can occur, leading to new combinations of knowledge (à la Schumpeter) and, finally, to shared (or socialised) innovation à la Engel (Armitage, Marschke and Plummer, 2008). As noted in the previous paragraph, this process is indispensable and strategic mainly because it allows the sharing of tacit knowledge. Organisational routines developed by the agricultural cooperative play a precious role in creating the conditions at the basis of this process of functioning. As Grant notes, these routines "include propinquity and 'low powered' incentives designed to foster coordination between individual specialists which avoid the problems of opportunism associated with the 'high powered' incentives

See Sacchetti and Tortia's contribution (2013). 
directly related to knowledge transactions" (Grant, 1996: 112).

Thus, the agricultural cooperative serves to create a common language and code by which it basically communicates "who knows what" and "how the process is organised" as indicated in Grant's contribution on the knowledge-based approach of the firm. In the agricultural cooperative, a particular (cognitive) proximity appears to lie in the relationship between the farmers and the technicians (i.e., agronomists). The latter could be meant as border spanners between the cooperative and the farmers and vice versa. They develop and upgrade their practice especially through the interaction with both the other co-op's divisions (practices) and the farmers (another practice). In both cases, the technicians acquire and provide relevant information that fosters social learning and innovation in (and along) the production system, or better, in the "agriculture practice". Specifically, this peculiarity allows the cooperatives to gather and manage the indigenous (farmers') knowledge (Bentley, 2006; Kummer et al., 2010).

However, generally speaking, the distinctiveness of the agricultural cooperative lies in its ability to identify sets of consistent routines at the various levels of production to disseminate the relevant agriculture practice by acting as a knowledge broker. By so doing, the agricultural cooperative links otherwise disconnected actors “... by helping transfer complex knowledge between different parties that are not directly related and rarely interact" (Ye and Kankanhalli, 2013: 76). In this regard, we can think of the importance of the agricultural cooperative in connecting farmers with research centres and universities. However, it is the ability to link the growers to all the nodes (knowledge domains) of the agri-food chain that represents the main competitive advantage of this institutional design. In fact, “...by exploiting strategic positions spanning multiple (knowledge) domains or industries, knowledge brokers (the agricultural cooperatives) consistently create new products or services by recognising and transferring ideas from where they are known to where they are unknown.” (ibid.: 77). In particular, agricultural cooperatives generate the conditions for establishing interdependencies among practices through a community-based mechanism based on shared norms and culture and within a cooperative project aimed at the creation of reciprocal beneficial outcomes. This means that the agricultural cooperative builds up an active and participated social context in which social interactions among stakeholders favour social learning and innovation along the agrifood chain. The stakeholders' bundle can include the farmers, the technicians and the salesmen but also the consumers, whereas they interact directly or indirectly with the production system defined by the cooperative's practices. In this sense, understanding the importance of developing a common language or code and a common identity becomes very intuitive.

From this viewpoint, the agricultural cooperatives' unique strength (which also confers a competitive advantage compared with other organisational types) seems to lie in their specific governance and property rights structure as well as in their social capital ${ }^{5}$. It is both the relational

\footnotetext{
5 However, there exist many quite different ownership and governance structures adopted by agricultural cooperatives in various countries. Future (empirical) research should consider this aspect to learn more about the consequences, including from a knowledge point of view.
} 
resources (Thompson, 2015; Thompson and Valentinov, 2017) as well as the institutional architecture that defines the agricultural cooperative, provide and institutionalise shared values which define the conditions for an equitable production, dissemination and use of knowledge (Sacchetti, 2004) or an efficient knowledge production ("the creation of new knowledge, the acquisition of existing knowledge, and storage of knowledge" à la Grant). Within a cooperative project, access to production and use of knowledge along the production system is consistent with the aim of upgrading producers' skills by means of mutual learning, their welfare and the overall quality of produce and products. Whereas Valentinov (2007) emphasised the strategic function of the agricultural cooperatives in fostering the division of labour in agriculture, aiming at maintaining a family-farm model to avoid the high monitoring costs of farming operations (Tortia, Valentinov and Iliopoulos, 2013), this contribution stresses the importance of agricultural cooperatives in preserving and developing a socialised knowledge system to create an environment conducive to innovation in agriculture. The proposed approach is complementary to the argument developed by Valentinov (2007) in the sense that the division of labour ensured by the agricultural cooperative is also functional in achieving a better organization (and functioning) of the production and dissemination of knowledge and innovation. This interpretation is useful for introducing a systemic organisational capability specific to the agricultural cooperative (Wallin and Von Krogh, 2010), which could develop a competitive advantage (Dyer and Singh, 1998) and ensure a Ricardian rent (Peteraf, 1993 as cited in Cook and Plunkett, 2006).

The study carried out on the Trentino agricultural cooperatives can help to understand the relevance of the proposed approach.

\section{Methodology}

In order to investigate this innovative function of agricultural cooperatives, an explorative qualitative analysis was structured. The main objective of the study was to analyse the role of agricultural cooperatives in managing the agri-food chain and, specifically, their ability in connecting farmers with the outside world and creating virtuous interdependencies to fuel the innovation process.

The study focussed on the agricultural cooperatives in the province of Trento. This area is located in North-East Italy and is characterised by a high cooperative density, especially with reference to the farming sector. The morphology of the territory, mainly dominated by mountains and valleys, determines a high land fragmentation and, as a consequence, the presence of a multitude of parttime family farms. Another reason for focussing on the Trentino Province is the long-standing tradition of agricultural cooperation, which was originally used by farmers to address poverty and low income levels (Ianes, 2003). Today, more than three quarters of the Trentino agriculture gross domestic product comes from farmers associated with agricultural cooperatives (Fontanari, 2018). 
It is also interesting to note that cooperatives tend to adopt the "service at cost" principle ${ }^{6}$ and operate on "one head - one vote" democratic rule, according to the nature and functioning of traditional, open membership cooperatives.

The research was conducted in 2018 on a representative sample of agricultural cooperatives operating in the province of Trento (see Table 1). The sample takes into account the dimensional, sectorial and territorial (valleys) distribution of the universe under investigation.

In this way, 19 agricultural cooperatives were identified with a total turnover in 2016 of 358 million EUR, equal to about $34 \%$ of the value recorded by all the Trentino agricultural cooperatives (Federazione Trentina della Cooperazione, 2017).

The data were collected by means of two questionnaires: the first one was administered to the manager of the cooperative and the second one to a selected group of members of each cooperative. A total of 135 members were involved in the survey ${ }^{7}$.

Table 1. Sample of Trentino agricultural cooperatives by sector and size

Turnover range (in million EUR)

\begin{tabular}{lccccc} 
& Micro (0-2.5) & Small (2.5-10) & Medium (10-50) & Large (>50) & Total \\
\hline Fruit and vegetables & 0 & 5 & 2 & 1 & 8 \\
\hline Wine & 0 & 1 & 3 & 1 & 5 \\
\hline Dairy & 0 & 4 & 0 & 0 & 4 \\
\hline Zootechnics & 0 & 1 & 1 & 0 & 2 \\
\hline Total & 0 & 11 & 6 & 2 & 19 \\
\hline
\end{tabular}

Source: own data.

The questions formulated in the questionnaires were aimed at investigating two main aspects: first, the coordination mechanisms and organisational practices adopted by the cooperative and the members' perception of these tools; and second, the mechanisms of innovation production and diffusion used by the cooperative and the role of members in the innovation process. Selected questions are reported in the tables in the results section below.

\footnotetext{
6 This operating principle is linked to the traditional agricultural cooperative nature (aim) and it implies that co-ops provide "... a service to their user-owners at the lowest possible cost rather than generate a profit for investors" (United States Department of Agriculture, 1993: 2)

7 This sample involves also some board members. The local farmers who are not members of cooperatives were not taken into consideration because the aim of the analysis was to study the dynamics within the cooperative model. In the future, it would be interesting to design and implement a comparative analysis among different organizational models.
} 


\section{Results}

The Trentino agricultural cooperatives highlighted as recurring practice the establishment of long-term relationships with the external environment (18 cooperatives out of 19). In particular, managers affirmed that the best way to update and integrate internal knowledge is through collaboration with other firms, which is usually multidisciplinary, ranging from agronomic to commercial and marketing competencies. The approach used is collaborative, since the relationship with external actors is based on a reciprocal exchange of information and knowledge aimed at developing new products and/or processes.

The Trentino agricultural cooperatives show a careful and almost total and increasing supervision and control of the knowledge chain (see Table 2). The relationship with the outside environment develops and fosters knowledge socialisation within the cooperative through the periodic planning of meetings among internal divisions (in two cooperatives out of three, especially in mediumlarge cooperatives ${ }^{8}$. These meetings are aimed at systemising information and knowledge gathered externally, including problems and instances encountered in each operational (knowledge) domain. In turn, cooperatives summarise and translate the outcomes of these processes to the benefit of growers-members through the convening of informative technical meetings. Actually, as we will see later, the role of the member in the knowledge chain is not merely receptive. The information flow between the cooperative and members is two-way.

The concept of open innovation coined by Chesbrough (2003) thus seems to explain the organisational routines of the Trentino agricultural cooperatives. In this regard, the engagement of external actors is as broad as possible, also involving consumers in the definition of innovation policies.

In the agri-food sector, what most differentiates agricultural cooperatives from other enterprise forms is the internalisation of the most strategic resource, the farmer. In fact, the alignment of agricultural production with the attributes required by the market implies a strict coordination along the entire supply chain. Consequently, the first actor to be involved is the farmer, on whom in large part (if not all; e.g., fresh fruit market) the quality of the final product depends. In this way, in the new market scenario (reversal chain) the role of the grower is clearly more important than in the past. The updating of agronomic practices, products and processes inevitably passes to the farmer, who has to implement them (adopt them) on his own farm.

For this reason, it is essential to have an intermediate institution acting as a chain coordinator. The research carried out in the province of Trento clearly shows the strategic importance of agricultural cooperatives from this point of view'. They summarise and systemise knowledge by

\footnotetext{
8 Nevertheless, all the agricultural cooperatives reported that they manage the internal circulation of information consciously.
}

9 Almost two-thirds of the cooperatives reported that they coordinate the members' activities significantly. 
standardising the production of members to market requests. This occurs through the definition and introduction of production protocols linked to strict quality management and control systems. The Trentino agricultural cooperatives carry out the activity of regulation and supervision both at the upstream and downstream levels (see Table 2). Substantially, these two procedures represent the synthesis of the social interaction (social theatre) that takes place in the agri-food chain and so the advancing of the innovation process.

Table 2. The managers' perception of the evolution of agricultural cooperative activities in the supply chain over the past 10 years. Percentage values.

\begin{tabular}{|c|c|c|c|c|c|c|c|c|}
\hline Activity & $\begin{array}{c}\text { Significant } \\
\text { decline }\end{array}$ & $\begin{array}{c}\text { Slight } \\
\text { downturn }\end{array}$ & Constant & $\begin{array}{l}\text { Slight } \\
\text { increase }\end{array}$ & $\begin{array}{c}\text { Significant } \\
\text { increase }\end{array}$ & Consortium & N/A & Total \\
\hline Input supply & 0.0 & 0.0 & 11.1 & 27.8 & 5.6 & 5.6 & 50.0 & 100.0 \\
\hline Storage & 0.0 & 10.5 & 15.8 & 31.6 & 26.3 & 0.0 & 15.8 & 100.0 \\
\hline Processing & 0.0 & 15.8 & 15.8 & 21.1 & 21.1 & 26.3 & 0.0 & 100.0 \\
\hline Packaging & 0.0 & 0.0 & 22.2 & 33.3 & 5.6 & 33.3 & 5.6 & 100.0 \\
\hline $\begin{array}{l}\text { Sale of fresh } \\
\text { products }\end{array}$ & 0.0 & 0.0 & 11.8 & 29.4 & 17.6 & 29.4 & 11.8 & 100.0 \\
\hline $\begin{array}{l}\text { Sale of processed } \\
\text { products }\end{array}$ & 0.0 & 0.0 & 29.4 & 35.3 & 11.8 & 23.5 & 0.0 & 100.0 \\
\hline Marketing & 0.0 & 5.3 & 15.8 & 26.3 & 21.1 & 31.6 & 0.0 & 100.0 \\
\hline $\begin{array}{l}\text { Quality } \\
\text { management } \\
\text { and control } \\
\text { system at the } \\
\text { downstream } \\
\text { level }\end{array}$ & 0.0 & 0.0 & 0.0 & 36.8 & 26.3 & 31.6 & 5.3 & 100.0 \\
\hline $\begin{array}{l}\text { Quality } \\
\text { management } \\
\text { and control } \\
\text { system at the } \\
\text { upstream level }\end{array}$ & 0.0 & 0.0 & 5.6 & 33.3 & 38.9 & 22.2 & 0.0 & 100.0 \\
\hline $\begin{array}{l}\text { Research and } \\
\text { development }\end{array}$ & 0.0 & 5.6 & 5.6 & 11.1 & 22.2 & 55.6 & 0.0 & 100.0 \\
\hline $\begin{array}{l}\text { Technical } \\
\text { assistance }\end{array}$ & 0.0 & 0.0 & 27.8 & 11.1 & 22.2 & 27.8 & 11.1 & 100.0 \\
\hline $\begin{array}{l}\text { Organizational, } \\
\text { financial and } \\
\text { management } \\
\text { consultancy }\end{array}$ & 0.0 & 0.0 & 35.3 & 11.8 & 11.8 & 5.9 & 35.3 & 100.0 \\
\hline
\end{tabular}

Source: own data. 
In this regard, both members and managers underline the pivotal role of the Trentino agricultural cooperatives in managing the innovation process in agriculture. In particular, more than $70 \%$ of the members emphasised the full synergy with the cooperative in this area, noting that the introduction of innovations is the result of joint work. As a consequence, members fully understand the importance of stringent regulations set by the agricultural cooperative: approximately $80 \%$ of interviewees considered the rules governing the member-cooperative relationship useful for the success of the farm.

In support of the growers' involvement in the innovation process, the research highlights a further alignment between members and managers regarding the perception of the amount of innovations introduced in recent years ${ }^{10}$. This result is derived from the perception declared by most members ( $77 \%$ of interviewees) that they play an active role in the innovation process, from which follows a greater awareness about life in the cooperative. In this way, being more involved, members are able to recognise the positive impact of innovations on farm performance ${ }^{11}$ (see Table 3). This virtuous circle is particularly important because it creates the right incentives for supporting the innovation process.

Table 3. Members' perceptions of their role in the innovation process and their evaluation of the impact of innovations on the farm competitiveness, on a scale of 1 to 5 . Percentage values.

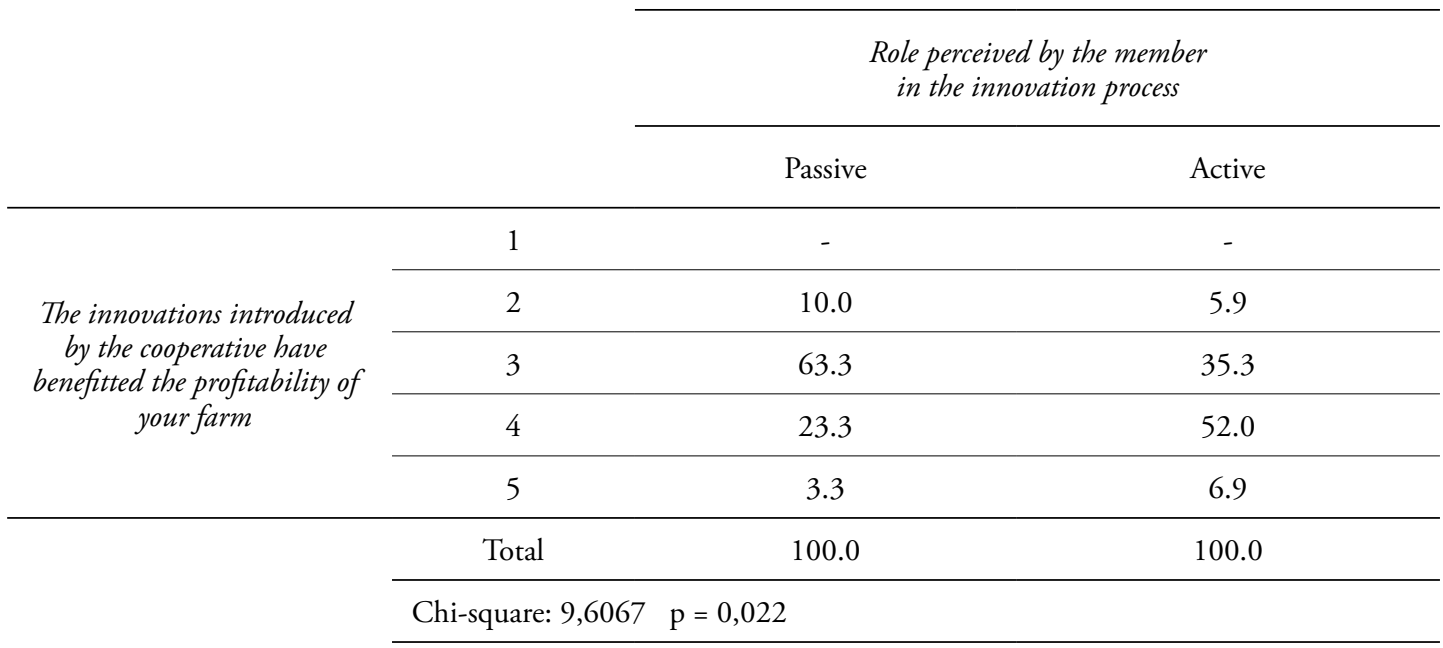

Source: own data.

10 Only $15 \%$ of members and one cooperative out of 19 affirm that the innovations introduced in the last 10 years have been few.

11 More than half of the members reported that the innovations introduced with the support of the cooperative had a very significant impact. 
The organisational design (interfaces, procedures, rules, etc.) set up by the Trentino agricultural cooperatives seems to favour the development of operating and social contexts, which take the form of real communities of practice. In this respect, the members confirm that, in running the farming activity, they are used to interacting mainly with the technicians and other members. In particular, $80 \%$ of interviewees claimed to interact with the other members constantly, above all during technical meetings scheduled by the cooperative. According to the members, this storytelling mechanism is very important because it usually promotes the identification of common problems and solutions (in more than three quarters of cases). In addition, with reference to experimental activity, the farmers reported that they always share with the technicians the results achieved during their experiments in the field. Then, in some cases, when the cooperative considers the discoveries made by the members to be relevant, the former disseminates the results to the entire membership.

In light of the above, the research demonstrates that, in the province of Trento, one of the main strengths of agricultural cooperatives is their capacity to stimulate a dense exchange of information with and among farmers. This empirical evidence clearly highlights a mechanism of perfect circulation of knowledge based on cooperative principles and, specifically, on the reciprocity principle. In this context, the right incentives to cooperate are in place and foster knowledge socialisation, which, in turn, stimulates the innovation process.

This new interpretation of the modern agricultural cooperative as a "knowledge engine" is recognised above all by the members, who assign to it a fundamental role in their professionalisation (see Table 4), emphasising the usefulness of the division of labour (tasks) working in the production system (farms plus cooperative).

Table 4. Members' evaluations of the role of the agricultural cooperative with respect to professionalisation and perceptions of the utility of the division of labour within the production system, on a scale of 1 to 5 . Percentage values.

Professionalisation

Division of labour

\begin{tabular}{ccc}
\hline 1 & 2.3 & - \\
\hline 2 & 3.1 & - \\
\hline 3 & 12.2 & 24.2 \\
\hline 4 & 75.6 & 50.0 \\
\hline 5 & 6.9 & 25.8 \\
\hline Total & 100.0 & 100.0 \\
\hline
\end{tabular}

Source: own data.

In this operational context, agricultural cooperatives are able to support the members constantly, providing them with technical assistance, information and training services. In this way, the cooperative develops in members the "skills to participate", so that they are aware of their role 
within the entire production system and are able to influence the determination of collective action, even in the innovation process.

A concrete example of this virtuous circuit is provided by the function attributed by both actors to innovation in introducing products and processes that promote environmental protection and the sustainable development of the territory ${ }^{12}$. This alignment is the result of the attention paid by the Trentino agricultural cooperatives to the training activity offered to members, which in turn represents the outcome of the interplay with external actors (stakeholders).

This empirical evidence confirms once again the role of agricultural cooperatives as border spanners. This intermediary function of the cooperative is strategic for growers' competitiveness, especially in the case of the province of Trento, an area characterised by a high density of part-time family farms.

In particular, when members recognise the new strategic function of the agricultural cooperative in the innovation process, their evaluation of the cooperative governance is positively affected. In this regard, the recognition of this new function seems to develop in members a (new) sense of belonging to a community of practice (the cooperative), which is based on the perception of being a co-owner and sharing the same values and principles (see Tables 5-9).

Table 5. Members' recognition of the new economic function of the agricultural cooperative and their perceptions of their participation in the decision-making process, on a scale of 1 to 5 . Percentage values.

Participation in the decision-making process

\begin{tabular}{|c|c|c|c|c|c|c|}
\hline & & & & & & \\
\hline & & 1 & 2 & 3 & 4 & 5 \\
\hline & 1 & 100.0 & 25.0 & 9.8 & 5.4 & 11.8 \\
\hline $\begin{array}{l}\text { Ine importance } \\
\text { of the role of the }\end{array}$ & 2 & 0.0 & 33.3 & 34.2 & 30.4 & 0.0 \\
\hline $\begin{array}{c}\text { agricultural cooperative } \\
\text { in the continuous }\end{array}$ & 3 & 0.0 & 41.7 & 46.3 & 41.1 & 35.3 \\
\hline introduction of & 4 & 0.0 & 0.0 & 9.8 & 23.2 & 41.2 \\
\hline & 5 & 0.0 & 0.0 & 0.0 & 0.0 & 11.8 \\
\hline & Total & 100.0 & 100.0 & 100.0 & 100.0 & 100.0 \\
\hline & Chi-squar & $\mathrm{p}=0$ & & & & \\
\hline
\end{tabular}

Source: own data. 
Table 6. Members' recognition of the new economic function of the agricultural cooperative and the perceptions of their "voice", on a scale of 1 to 5 . Percentage values.

Your suggestions are taken into consideration by the cooperative

\begin{tabular}{lcccccc}
\cline { 2 - 6 } & & 1 & 2 & 3 & 4 & 5 \\
\hline \multirow{2}{*}{$\begin{array}{c}\text { The importance of the } \\
\text { role of the agricultural } \\
\text { cooperative in the }\end{array}$} & 1 & 100.0 & 16.7 & 11.7 & 1.8 & 5.9 \\
\cline { 2 - 7 } $\begin{array}{c}\text { continuous introduction } \\
\text { of innovations }\end{array}$ & 2 & 0.0 & 41.7 & 30.3 & 30.4 & 11.8 \\
\cline { 2 - 7 } & 4 & 0.0 & 41.7 & 51.2 & 39.3 & 35.3 \\
\hline & 0.0 & 0.0 & 7.0 & 26.8 & 17.7 \\
\cline { 2 - 7 } & Total & 100.0 & 100.0 & 100.0 & 100.0 & 100.0 \\
\hline
\end{tabular}

Source: own data.

Table 7. Members' recognition of the new economic function of the agricultural cooperative and their satisfaction regarding the information exchange with the cooperative, on a scale of 1 to 5 . Percentage values.

Satisfaction regarding the information exchange with the cooperative

\begin{tabular}{|c|c|c|c|c|c|c|}
\hline & & & & & & \\
\hline & & 1 & 2 & 3 & 4 & 5 \\
\hline \multirow{7}{*}{$\begin{array}{l}\text { The importance of the } \\
\text { role of the agricultural } \\
\text { cooperative in the } \\
\text { continuous introduction } \\
\text { of innovations }\end{array}$} & 1 & 0.0 & 0.0 & 0.0 & 1.8 & 0.0 \\
\hline & 2 & 0.0 & 50.0 & 9.3 & 1.8 & 0.0 \\
\hline & 3 & 100.0 & 41.7 & 51.2 & 36.4 & 29.4 \\
\hline & 4 & 0.0 & 8.3 & 39.5 & 52.7 & 52.9 \\
\hline & 5 & 0.0 & 0.0 & 0.0 & 7.3 & 17.7 \\
\hline & Total & 100.0 & 100.0 & 100.0 & 100.0 & 100.0 \\
\hline & \multicolumn{6}{|c|}{ Chi-square: $54,2137 \quad \mathrm{p}=0,000$} \\
\hline
\end{tabular}

Source: own data. 
Table 8. Members' recognition of the new economic function of the agricultural cooperative and their perceptions of sharing the same values and principles with other members, on a scale of 1 to 5 . Percentage values.

\begin{tabular}{|c|c|c|c|c|c|c|}
\hline & & \multicolumn{5}{|c|}{ Members share the same values and principles } \\
\hline & & 1 & 2 & 3 & 4 & 5 \\
\hline \multirow{7}{*}{$\begin{array}{l}\text { The importance of the } \\
\text { role of the agricultural } \\
\text { cooperative in the } \\
\text { continuous introduction } \\
\text { of innovations }\end{array}$} & 1 & 100.0 & 25.0 & 9.3 & 1.8 & 0.0 \\
\hline & 2 & 0.0 & 50.0 & 32.6 & 17.9 & 11.8 \\
\hline & 3 & 0.0 & 25.0 & 37.2 & 50.0 & 35.3 \\
\hline & 4 & 0.0 & 0.0 & 18.6 & 28.6 & 41.2 \\
\hline & 5 & 0.0 & 0.0 & 2.3 & 1.8 & 11.8 \\
\hline & Total & 100.0 & 100.0 & 100.0 & 100.0 & 100.0 \\
\hline & \multicolumn{6}{|c|}{ Chi-square: $41,9594 \quad p=0,000$} \\
\hline
\end{tabular}

Source: own data.

Table 9. Members' recognition of the new economic function of the agricultural cooperative and their perceptions of being co-owners with other members, on a scale of 1 to 5 . Percentage values.

You feel like a co-owner with the other members

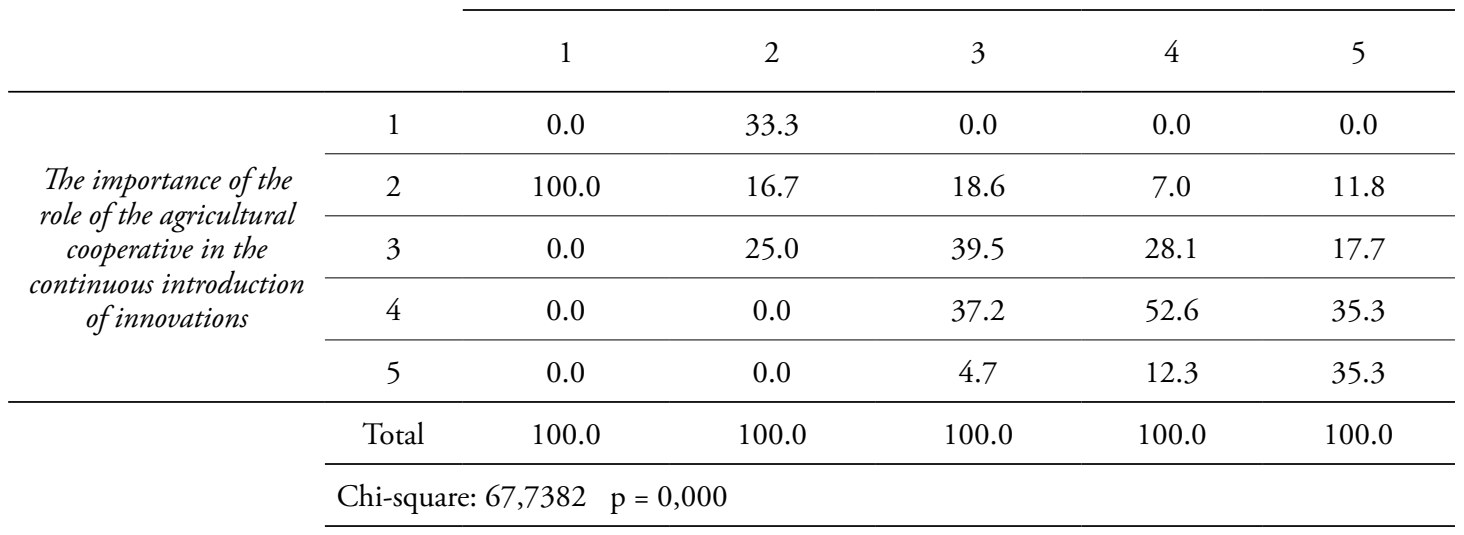

Source: own data. 


\section{Conclusions}

This explorative contribution investigates and stresses a new complementary economic function of modern agricultural cooperatives. The actual agri-food market requires knowledge-intensive farming production in the sense that consumers ask for produce with specific qualitative attributes. Therefore, the link between growers and the other nodes of the supply chain is becoming a strategic element of farm competitiveness. For this reason, the presence of an intermediate institution is central for developing in the agricultural production process a network among strategic actors.

It is in this context that the strategic and operational activities of agricultural cooperatives seem to be effective. The support in terms of internal/external specialised knowledge that the cooperative makes available to farmers-members allows the synthesis of the needs of the entire supply chain and enables the creation of a common code and language that leads to the definition of a production system. Thanks to this result, growers, but also the agri-food chain as a whole, benefit from the knowledge socialisation that activates a constant and very important process of innovation production and diffusion. In this regard, one of the main aspects highlighted by this study is that the driving factor of this process relies on institutional mechanisms (or incentives), intrinsic to the cooperative nature, facilitating face-to-face interactions, above all among the growers and between farmers and technicians.

In particular, this new function of agricultural cooperatives seems to have important implications not only in terms of the competitiveness of farms. In fact, the modern agricultural cooperative can be strategic in promoting and creating real communities of practice characterised by a new sense of belonging and a higher involvement and participation of growers. This represents a huge advantage for the sustainability and the correct functioning of the cooperative model and of the communities where farms are embedded.

This contribution supports the need for further research to better understand the organisation of agri-food chains and the role that cooperative producer organisations already play. A deeper understanding can usefully inform policies and strategies for assessing and fostering the cooperative model in agriculture and, above all, for improving the efficiency of the entire supply chain and the effectiveness of cooperation in accruing member and community welfare.

The results discussed in this work concern a peculiar territory in which the cooperative model is historically rooted and works by means of embedded and shared knowledge, reflected in common values and operational principles. In this regard, an important question to be addressed is: what would be the implications if this same study was conducted in other regions of Italy, or in other parts of the world characterized by different values and institutional setting, by means for instance of ownership and governance structures? Facing this question could represent an interesting development of the explorative research presented in this article and it could stimulate further reflections and inform a comparative research agenda. 


\section{References}

Agwu, A.E., Dimelu, M.U. \& Madukwe, M.C. (2008). Innovation system approach to agricultural development: Policy implications for agricultural extension delivery in Nigeria, African Journal of Biotechnology, 7(11): 1604-1611. DOI: https://doi.org/10.5897/AJB08.289

Akkoyunlu, S. (2013). Agricultural Innovations in Turkey, NCCR Trade Working Paper n. 2013|30.

Anandajayasekeram, P. (2011). The Role of Agricultural R\&D within the Agricultural Innovation Systems Framework. ASTI/IFPRI-FARA Conference, Accra, Ghana, December.

Armitage, D., Marschke, M. \& Plummer, R. (2008). Adaptive co-management and the paradox of learning, Global Environmental Change, 18(1): 86-98. DOI: https://doi.org/10.1016/j.gloenvcha.2007.07.002

Bentley, J.W. (2006). Folk experiments, Agriculture and Human values, 23: 451-462. DOI: https://doi.org/10.1007/ s10460-006-9017-1

Berkhout, G., Hartmann, D., Trott, P. (2010). Connecting technological capabilities with market needs using cyclic innovation model, R\&D Management, 40(5):474-490. DOI: https://doi.org/10.1111/j.1467-9310.2010.00618.x

Bigliardi, B., Galati, F. (2013). Models of adoption of open innovation within the food industry, Trends in Food Science \& Technology, 30(1): 16-26. DOI: https://doi.org/10.1016/j.tifs.2012.11.001

Bijman, J., Muradian, R. \& Cechin, A. (2011). Agricultural cooperatives and value chain coordination. In: A.H.J Helmsing \& S. Vellema (Eds.), Value Chains, Social Inclusion and Economic Development: contrasting theories and realities. Milton Park: Routledge, pp. 82-101.

Brown, J.S. \& Duguid, P. (1991). Organizational Learning and Communities-of-Practice: Toward a Unified View of Working, Learning, and Innovation, Organization Science, 2(1): 40-57. DOI: https://doi.org/10.1287/ orsc.2.1.40

Cechin, A. (2013). Governance of the member-cooperative relationship: a case from Brazil. Wageningen: Wageningen University.

Chaddad, F. \& Cook, M. (2004). Understanding New Cooperative Models: An Ownership-Control Rights Typology, Review of Agricultural Economics, 26(3): 348-360. DOI: https://doi.org/10.1111/j.1467-9353.2004.00184.x

Chesbrough, H. (2003). Open Innovation: The New Imperative for Creating and Profiting from Technology, Boston: Harvard Business School Press.

Cohen, W.M. \& Levinthal, D.A. (1989). Innovation and learning: The two faces of R\&D, The Economic Journal, 99(397): 569-596. DOI: https://doi.org/10.2307/2233763

Cohen, W.M. \& Levinthal, D.A. (1990). Absorptive Capacity: A New Perspective on Learning and Innovation, Administrative Science Quarterly, 35(1): 128-152. DOI: https://doi.org/10.2307/2393553

Cook, M. (1995). The future of U.S. Agricultural Cooperatives: A Neo-Institutionalist Approach, American Journal of Agricultural Economics, 77(5): 1153-1159. DOI: https://doi.org/10.2307/1243338

Cook, M. \& Iliopoulos (2000). Ill-defined Property Rights in Collective Action: The Case of US Agricultural Cooperatives. In: C. Menard (eds.), Institutions, Contracts, and Organizations: Perspectives from New Institutional Economics, pp. 335-348. London, UK: Edward Elgar Publishing. DOI: https://doi.org/10.4337/9781781952764.00036

Cook, M.L. \& Burress, M.J. (2009). A Cooperative Life Cycle Framework. Columbia, MO: University of Missouri. Available at: http://departments.agri.huji.ac.il/economics/en/events/p-cook.pdf [Accessed: 19 $9^{\text {th }}$ April 2016]

Cook, M.L. \& Plunkett, B. (2006). Collective Entrepreneurship: An Emerging Phenomenon in Producer-Owned Organizations, Journal of Agricultural and Applied Economics, 38(2): 421-428. DOI: https://doi.org/10.1017/ S1074070800022458

Dyer, J.H. \& Singh, H. (1998). The Relational View: Cooperative Strategy and Sources of Interorganizational Competitive Advantage, The Academy of Management Review, 23(4): 660-679. DOI: https://doi.org/10.5465/ amr.1998.1255632 
Dyer, J.H. \& Nobeoka, K. (2000). Creating and Managing a High-Performance Knowledge-Sharing Network: The Toyota Case, Strategic Management Journal, 21(3): 199-425. DOI: https://doi.org/10.1002/(SICI)10970266(200003)21:3<345::AID-SMJ96>3.0.CO;2-N

Engel, P.G.H. (1995). Facilitating innovation: an action oriented approach and participatory methodology to improve innovative social practice in agriculture. Wageningen: Wageningen University.

Federazione Trentina della Cooperazione (2017), Relazione Convegno Cooperative agricole, Trento.

Feng, L. \& Hendrikse, G. (2011). Coordination and Governance: The case of Cooperatives versus IOFs, paper presented at EAAE 2011 Congress - Change and Uncertainty, 30 August - 2 September 2011, Zurich, Switzerland. Available at: http://ageconsearch.umn.edu/bitstream/114359/2/Feng_Li_326.pdf [Accessed: 22 ${ }^{\text {th }}$ March 2017].

Folmer C., Keyser M. A., Merbis M. D., Stolwijk H. J. J., Veenendaal P. J. J. (1995). The Common Agricultural Policy Beyond the MacSharry Reform. Amsterdam: NorthHolland.

Fontanari, E. (2014). La cooperazione italiana. Funzione e rilevanza economica: un focus particolare sui settori non bancari (Ph.D. Dissertation). University of Insubria, Italy.

Fontanari, E. (2017). The Modern Agricultural Cooperative: A Cognitive-Knowledge-Based Approach, Euricse Working Papers, 91|17. DOI: https://doi.org/10.2139/ssrn.2940320

Fontanari, E. (2018). Cooperazione agricola e aree marginali: una riflessione sull'esperienza della Provincia di Trento, Euricse Working Papers, 102|18. DOI: https://doi.org/10.2139/ssrn.3160842

Foss, N. J. (1993). Theories of the firm: contractual and competence perspectives, Journal of Evolutionary Economics, 3(2): 127-144. DOI: https://doi.org/10.1007/BF01213830

Garcia-Winder, M., Riveros, H., Pavez, I., Rodriguez, D., Lam, F. Arias, J. \& Herrera, D. (2009). Agrifood chains: a tool for strengthening the institutional framework of the agricultural and rural sector, Perspectives, May-August 2009. Inter-American Institute for Cooperation on Agriculture (IICA).

Garofoli, G. (2003). Economic development, organization of production and territory, Revue d'économie industrielle, 64(1): 22-37. DOI: https://doi.org/10.3406/rei.1993.1475

Giannakas, K. \& Fulton, M. (2005). Process Innovation Activity in a Mixed Oligopoly: The Role of Cooperatives, American Journal of Agricultural Economics, 87(2): 406-422. DOI: https://doi.org/10.1111/j.1467-8276.2005.00731.x

Goldsmith, P.D. \& Bender, K. (2004). Ten Conversations about Identity Preservation, Journal of Chain and Network Science, 4(2): 111-123. DOI: https://doi.org/10.3920/JCNS2004.x046

Grandori, A. (2001). Neither Hierarchy nor Identity: Knowledge-Governance Mechanisms and the Theory of the Firm, Journal of Management and Governance, 5: 381-399. DOI: https://doi.org/10.1023/A:1014055213456

Grant, R.M. (1996). Toward a knowledge-based theory of the firm, Strategic Management Journal, 17(S2): 502-518. DOI: https://doi.org/10.1002/smj.4250171110

Hayek, F. A. (1945). The use of knowledge in society. The American economic review, 35(4): 519-530.

Hendrikse, G.W.J. \& Veerman, C.P. (2001). Marketing Cooperatives and financial structure: a transactional costs economics analysis, Agricultural Economics, 26: 205-216. DOI: https://doi.org/10.1111/j.1574-0862.2001. tb00064.x

Ianes, A. (2003). La cooperazione trentina dal secondo dopoguerra alle soglie del terzo millennio. Trento: Edizioni31.

Knickel, K., Brunori, G., Rand, S. \& Proost, S. (2009). Towards a better Conceptual Framework for Innovation Processes in Agriculture and Rural Development: From Linear Models to Systemic Approaches, The Journal of Agricultural Education and Extension, 15: 131-145. DOI: https://doi.org/10.1080/13892240902909064

Kogut, B. (2000). The network as knowledge: generative rules and the emergence of structure, Strategic Management Journal, 21(3): 405-425. DOI: https://doi.org/10.1002/(SICI)1097-0266(200003)21:3<405::AIDSMJ103>3.0.CO;2-5

Kogut, B. \& Zander, U. (1992). Knowledge of the Firm, Combinative Capabilities, and the Replication of Technology, Organization Science, 3(3): 383-397. DOI: https://doi.org/10.1287/orsc.3.3.383 
Kogut, B. \& Zander, U. (1993). Knowledge of the Firm and the Evolutionary theory of the Multinational Corporation, Journal of International Business Study, 24(4): 625-645. DOI: https://doi.org/10.1057/palgrave.jibs.8490248

Kogut, B. \& Zander, U. (1996). What firms do? Coordination, identity, and learning, Organization Science, 7(5): $502-$ 518. DOI: https://doi.org/10.1287/orsc.7.5.502

Kummer, S., Aigelspergerb, L., Milestade, R., Chowdhuryb, A.H. \& Vogla, C.R. (2010). Knowledge systems, innovations and social learning in organic farming - An overview. Paper presented at the 9th European IFSA Symposium, 4-7 July 2010, Vienna, Austria.

Lewin, A. Y., Massini, S., \& Peeters, C. (2011). Microfoundations of internal and external absorptive capacity routines, Organization science, 22(1): 81-98. DOI: https://doi.org/10.1287/orsc.1100.0525

Loasby, B. J. (2006). Industrial organization. In: T. Raffaelli, G. Becattini, \& Marco Dardi (Eds.), The impact of Alfred Marshall's ideas: the global diffusion of his work. Cheltenham, UK: Edward Elgar, pp. 371-378. Available at: http:// eh.net/book_reviews/the-elgar-companion-to-alfred-marshall/ [Accessed: $20^{\text {th }}$ Februray 2020]

Mäkimattila, M., Melkas, H., Uotila, T. (2013). Dynamics of Openness in Innovation Processes - A case study in the Finnish Food Industry, Knowledge and Process Management, 20: 243-255. DOI: https://doi.org/10.1002/ kpm.1421

Mariano, S., \& Al-Arrayed, S. (2018). Combinations of absorptive capacity metaroutines: the role of organizational disruptions and time constraints, European Management Journal,36(2): 171-182. DOI: https://doi.org/10.1016/j. emj.2017.03.003

Medeiros, G., Binotto, E., Caleman, S. \& Florindo, T. (2016). Open Innovation in Agrifood Chain: A Systematic Review, Journal of Technology Management \& Innovation, 11: 108-116. DOI: https://doi.org/10.4067/S071827242016000300013

Minh T.T., Neef, A. \& Hoffmann, V. (2011). Agricultural Knowledge Transfer and Innovation Processes in Vietnam's Northwestern Uplands: State-governed or Demand-driven?, Southeast Asian Studies, 48(4): 425-455.

Nelson, R. R., \& Winter, S. G. (1982). An Evolutionary Theory of Economic Change. Cambridge, MA: Belknap Press. Available at: http://inctpped.ie.ufrj.br/spiderweb/pdf_2/Dosi_1_An_evolutionary-theory-of_economic_ change..pdf [Accessed: 20 $0^{\text {th }}$ Februray 2020]

Nilsson, J. (2001). Organisational Principles for Co-operative firms, Scandinavian Journal of Management, 17(3): 329356. DOI: https://doi.org/10.1016/S0956-5221(01)00010-0

Nonaka, I., \& Takeuchi, H. (1995). The Knowledge Creating Company: How Japanese Companies Create The Dynamics Of Innovation. New York: Oxford University Press. DOI: https://doi.org/10.1016/S0040-1625(96)00091-1

Nooteboom, B., Van Haverbeke, W., Duysters, G., Gilsing, V. \& van den Oord, A. (2007). Optimal cognitive distance and absorptive capacity, Research Policy, 36(7): 1016-1034. DOI: https://doi.org/10.1016/j.respol.2007.04.003

Parrilli, M. D., \& Sacchetti, S. (2008). Linking learning with governance in networks and clusters: key issues for analysis and policy, Entrepreneurship and Regional Development, 20(4): 387-408. DOI: https://doi. org/10.1080/08985620801886463

Peteraf, M. (1993). The cornerstones of competitive advantage: A resource-based view, Strategic Management Journal, 14: 179-191. DOI: https://doi.org/10.1002/smj.4250140303

Polanyi, M. (1966). The tacit dimension. London: Routledge \& Kegan Paul. Available at: https:/www.worldcat.org/title/ tacit-dimension/oclc/60901005[Accessed: 20 $0^{\text {th }}$ Februray 2020]

Porter, M. E. (1990). The Competitive Advantage of Nations. New York: Free Press.

Porter, M. E. (2001). The value chain and competitive advantage. In: D. Barnes (Ed.), Understanding Business Processes. London: Routledge, pp. 50-66.

Richardson, G. B. (1972). The organisation of industry, The economic journal, 82(327): 883-896. DOI: https://oi. org/10.2307/2230256 
Sacchetti, S., \& Sugden, R. (2003). The governance of networks and economic power: the nature and impact of subcontracting relationships, Journal of Economic Surveys, 17(5): 669-692. DOI: https://doi.org/10.1046/j.14676419.2003.00209.x

Sacchetti, S. (2004). Knowledge caps in industrial development, New Political Economy, 9(3):389-412. DOI: https://doi. org/10.1080/1356346042000259848

Sacchetti, S. (2009). Why, where and with whom do you link? The nature and motivations of linkages within and outside an Italian local system, Regional Studies, 43(2): 197-209. DOI: https://doi.org/10.1080/00343400701808840

Sacchetti, S. \& Tortia, E. C. (2013). The Internal and External Governance of Cooperatives: Membership and Consistency of Values, Euricse Working Paper, 62|13. DOI: https://doi.org/10.2139/ssrn.2326938

Sexton, R.J. \& Iskow, J. (1988). Factors critical to the success or failure of emerging agricultural cooperatives, Giannini Foundation Information Series n. 88-3, Division of Agriculture and Natural Resources, University of California, June.

Shaffer, J. D. (1987). Thinking about farmers' cooperatives, contracts, and economic coordination, ACS Service Report 18, Agricultural Cooperative Service, US Department of Agriculture, pp. 61-86.

Simon, H. A. (1991). Bounded rationality and organizational learning, Organization Science, 2(1): 125-134. DOI: https://doi.org/10.1287/orsc.2.1.125

Spender, J.-C. (1996). Making knowledge the basis of a dynamic theory of the firm. Strategic Management Journal, 17(S2): 45-62. DOI: https://doi.org/10.1002/smj.4250171106

Sporleder, T.L. (2006). Strategic Alliances and Networks in Supply Chains. In: C.J.M. Ondersteijn, J.H.M Wijnands, R.B.M. Huirne \& O. van Kooten (Eds.), Quantifying the agri-food supply chain. The Netherlands: Springer, pp. 159-169.

Sporleder, T.L. \& Boland, M.A. (2011). Exclusivity of Agrifood Supply Chains: Seven Fundamental Economic Characteristics, International Food and Agribusiness Management Review, 14(5): 27-52.

Sporleder, T.L. \& Wu, S.Y. (2006). Social capital and vertical ties in agrifood supply chains, Journal on Chain and Network Science, 6: 1-7. DOI: https://doi.org/10.3920/JCNS2006.x060

Sporleder, T., Jackson, C.C. \& Bolling, D. (2005). Transitioning from transaction-based markets to alliance-based supply chains: implications for firms, Choices, 20(4): 175-180.

Sporleder, T. \& Peterson, H.C. (2003). Intellectual capital, learning, and knowledge management in agrifood supply chains, Journal on Chain and Network Science, (2): 75-80. DOI: https://doi.org/10.3920/JCNS2003.x031

Sporleder, T.L. \& Moss, L.A.E. (2002). Knowledge management in the global food system: network embeddedness and social capital, American Journal of Agricultural Economics, 84(5): 1345-1352. DOI: https://doi.org/10.1111/14678276.00400

Sporleder, T.L. \& Goldsmith, P.D. (2001). Alternative Firm Strategies for Signaling Quality in the Food System, Canadian Journal of Agricultural Economics 49(4): 591-604. DOI: https://doi.org/10.1111/j.1744-7976.2001.tb00329.x

Sulaiman, V.R. \& Hall, A. (2002). Beyond technology dissemination: reinventing agricultural extension, Outlook on Agriculture, 31(4): 225-233. DOI: https://doi.org/10.5367/000000002101294119

Thompson, S. (2015). Towards a social theory of the firm: worker cooperatives reconsidered. Journal of Co-operative Organization and Management, 3(1): 3-13. DOI: https://doi.org/10.1016/j.jcom.2015.02.002

Thompson, S., \& Valentinov, V. (2017). The neglect of society in the theory of the firm: a systems-theory perspective. Cambridge Journal of Economics, 41(4): 1061-1085. DOI: https://doi.org/10.1093/cje/bew072

Tortia, E.C., Valentinov, V. \& Iliopoulos, C. (2013). Agricultural cooperatives. Journal of Entrepreneurial and Organizational Diversity, 2(1): 23-36. DOI: http://dx.doi.org/10.5947/jeod.2013.002

Tushman, M., Lakhani, K., Lifshitz-Assuf, H. (2012). Open innovation and organization design, Journal of Organizational Design, 1: 24-27. DOI: https://doi.org/10.7146/jod.2012.1.8 
United States Department of Agriculture (1993). What are Patronage Refunds?, Cooperative Information Report n. 9, Agriculture Cooperative Service, Washington, D.C.

Valentinov, V. (2007). Why are cooperatives important in agriculture? An organizational economics perspective, Journal of Institutional Economics, 3(1): 55-69. DOI: https://doi.org/10.1017/S1744137406000555

Wallin, M.W., Von Krogh, G. (2010). Organizing for Open Innovation: Focus on the Integration of Knowledge, Organizational Dynamics, 39: 14-154. DOI: https://doi.org/10.1016/j.orgdyn.2010.01.010

Ward, R. W. (1982). Asymmetry in retail wholesale and shipping, point pricing for fresh vegetables, American Journal of Agricultural Economics, 62: 205-212. DOI: https://doi.org/10.2307/1241124

Willem, A. \& Buelens, M. (2009). Knowledge sharing in inter-unit cooperative episodes: The impact of organizational structure dimensions, International Journal of Information Management, 29: 151-160. DOI: https://doi. org/10.1016/j.ijinfomgt.2008.06.004

World Bank (2006). Enhancing Agricultural Innovation: How to go beyond the strengthening of Research Systems. Washington DC: The World Bank. DOI: https://doi.org/10.1596/978-0-8213-6741-4

World Bank (2008). Agricultural Innovation Systems: From Diagnostics toward Operational Practices. Washington DC: The World Bank.

Ye, J., Kankanhalli (2013). Exploring innovation through open networks: A review and initial research questions, IIBM Management Review, 25: 69-82. DOI: https://doi.org/10.1016/j.iimb.2013.02.002

Zahra, S. A. \& George, G. (2002). Absorptive capacity: a review, reconceptualization, and extension, Academy of Management Review, 27: 185-203. DOI: https://doi.org/10.5465/amr.2002.6587995 